\title{
Ethnologies
}

\section{Alison R. Marshall. The Way of the Bachelor: Early Chinese Settlement in Manitoba. (Vancouver: 2011, University of British Columbia Press. Pp. xv-226. ISBN 978-0-7748-1916-9)}

\section{$\mathrm{Mu} \mathrm{Li}$}

Volume 34, numéro 1-2, 2012

URI : https://id.erudit.org/iderudit/1026158ar

DOI : https://doi.org/10.7202/1026158ar

Aller au sommaire du numéro

Éditeur(s)

Association Canadienne d'Ethnologie et de Folklore

ISSN

1481-5974 (imprimé)

1708-0401 (numérique)

Découvrir la revue

Citer ce compte rendu

Li, M. (2012). Compte rendu de [Alison R. Marshall. The Way of the Bachelor: Early Chinese Settlement in Manitoba. (Vancouver: 2011, University of British Columbia Press. Pp. xv-226. ISBN 978-0-7748-1916-9)]. Ethnologies, 34(1-2),

323-326. https://doi.org/10.7202/1026158ar d'utilisation que vous pouvez consulter en ligne.

https://apropos.erudit.org/fr/usagers/politique-dutilisation/ 
and virtually no information on railway porters.

The most impressive part of the book is the collection of photographs that MacDonald gathered from a multitude of different museums and private collections across Cape Breton Island. MacDonald managed to find photos of almost every locomotive that served the island, as well as several images of the island's railway stations. For this reason alone, it would be a welcome addition to any Cape Breton or railway history collection. Further, MacDonald is clearly an expert in the Maritime railway and this book is the culmination of an impressive amount of research into a topic that has little or no source material. Cape Breton Railways will be a key resource for any future research into rail lines and industry in Cape Breton. Despite the narrow focus, this book will have broader appeal to those with an interest in transportation and the development of railways in Canada.

Vanessa Childs Rolls

Memorial University

Alison R. Marshall. The Way of the Bachelor: Early Chinese Settlement in Manitoba. (Vancouver: 2011, University of British Columbia Press. Pp. xV-226. ISBN 978-0-7748-1916-9)

The Way of the Bachelor is a history of early Chinese immigrants to Western Manitoba and adjacent areas. The group history is successfully told through the stories of individuals who might be different from each other in various ways, but due to the institutional and social context, experienced similar life patterns in the Canadian Prairies in the period between their first arrival and the repeal of the Canadian Chinese Immigration Act (1884-1947). This life pattern is termed "the way of the bachelor," which refers to a process of Chinese settlers, who were often separated from their families in China and forced to live with other males of the same ethnicity, forming relationships, becoming nominal Christians, and winning the respect of the town people (108). The similar contextual situation and life track define a united Chinese community: "Chinese men who worked together in laundries and cafes may not have been brothers by blood, but 
they were perceived to be family and, therefore, as 'brothers' by race" (11). In the same vein of Benedict Anderson, Marshall constantly reminds us that a group identity is not born, but imagined, and sometimes emerges as a strategy to cope with social reality. Marshall, therefore, suggests that the choice of personal free will in certain social circumstances consciously or unconsciously facilitates the construction of the collective pattern.

On the other hand, Marshall is aware of the tension between collectiveness and individuality. Inspired by Erving Goffman, she understands that personal identity in many cases is situational and multiple. Marshall writes, "Thus, bachelors behaved as Christians on the front stage and in more traditional ways on the back stage" (12). The behavioral differences in public and private spaces is attributed to the desires of Chinese individuals to "fit into local communities, their increased involvement with the KMT [Chinese Nationalist League or Kuomingtang] and other Chinese political and social institutions, religious ambivalence, the ambiguous nature of Chinese religion, and efficacy" (23). However, the nominal identity as Christian on the front stage of the life of Chinese settlers does not indicate Chinese deception of religious affiliation; rather, Marshall insightfully points out that ambiguity is the most salient characteristic of Chinese immigrants' identity, which "incorporated modern Chinese ideas (which emerged around 1900), Western Christian ideas, and Confucian and Nationalist ideas" (2).

This ambiguity of the Chinese identity is thought to be associated with the historical and social settings of the Canadian Prairies. Marshall notices that, unlike metropolitan centers such as Vancouver and Toronto with a considerable Chinese population to support more traditional Chinese culture and customs, Chinese identity in the Prairie Provinces was often under negotiation in the dilemma between being acculturated and being traditional. Marshall realizes that the Chinese restaurants in the Prairies, especially those in small towns, as well as the food they served, provided Chinese and non-Chinese a place for discussion. She notes, "The Chinese café is a complex space representing the intersection and flow of multiple cultures, commodities, and identities" (125). According to Marshall, "food communicates the ambiguities of diaspora identity, labour, and community formation" (14) and "[t]hrough the food they offered, the restaurants provided a way for people to transcend the boundaries of gender, race, class, religion, and nation" (125). Instead of exploring the differences between food served in these Western Manitoban cafes and that in more "traditional" 
Chinese eateries and pursuing the solution of the debate on authenticity, Marshall mainly focuses on the role of Chinese restaurants and their food in the construction of a modern and acceptable Chinese identity. This new identity emerged from the bridged division between East and West, which has been blurred through "blending traditional and Chinese Canadian foods and offering a décor that included traditional architectural details" (105).

The modern Chinese identity in the Canadian Prairies, as Marshall claims, demonstrates the way of the bachelor, who actually employed traditional knowledge to cope with social harshness and cultural difficulties in everyday practice. Early Chinese settlers actually transformed the unfamiliar to the familiar in many occasions to satisfy both themselves and the general public of the host society. Marshall uncovers that, although Chinese nominal Christians seemingly committed to religious activities, their perceptions on these involvements were highly traditional. For example, Marshall writes, 'while they call the gathering 'church,' there are no religious elements involved except for the fellowship and the social heat produced" (57).

At the end of The Way of the Bachelor, Marshall reminds us that the modern Chinese identity in the Canadian Prairies only belongs to those early settlers and it is not transferrable from the older generation to their descendants because of the shifting of the political, social and cultural context. Younger generations would be educated by the old timers with those stories in the past, but they may not be able or willing to follow the way of the bachelor. As Marshall concludes, "For second-and latergeneration Chinese Canadians...they were unlike their parents and other family members... For them, there was little or no dislocation between their front-stage and back-stage religiosity. They did not have to rely on people outside their family and they had personal freedom. Their boundaries did not need to be as porous as did those of their forebears. Social acceptance and life in present-day Manitoba is more complicated than it was in the Manitoba of their parents and grandparents. And, in many ways, "it is easier" (162). Personal identity is not repeatable.

Alison Marshall never attempted to write a folklore book, but her work on the shifting of group values and cultures of multi-generational Chinese immigrants to Western Manitoba inspires folklorists in many ways, especially when discussing identity issues. Her writing well presents the complexity of personal identity and her insights encourage us to look at how identity (group or personal) is constructed, negotiated, and recreated 
in individual, situational and generational dimensions along with the changes of social and cultural backgrounds.

$\mathrm{Mu} \mathrm{Li}$

Memorial University

Jon Bartlett and Rika Ruebsaat. Dead Horse on the Tulameen: Settlers Verse From BC's Similkameen Valley. (Princeton: 201 1, Canadian Folk Workshop. Pp. 293. ISBN: 978-0-9877255-0-9)

Bartlett and Ruebsaat present a fairly straightforward project familiar to several studies both popular and scholarly: using a popular local tradition to describe and, at times, interpret the public history and geographic context of a place. In this study, the authors use the popular verse tradition to explore the British Columbian rural communities in the Similkameen Valley. From 1890 to 1960, seven communities emerged in this historically isolated southern valley that is now reached by the Crow's Nest Highway and centred around the small city of Princeton.

The work attempts to straddle the popular-academic divide and generally manages to do so, but only after a disastrous preface and the first half of an introductory chapter. The authors initially fail to properly delineate their topic, while also offering a clumsy interpretation of folk culture which manages to perpetuate history as technological determinism, as well as the archaic disappearing folklore model. Neither of these sections are necessary. The authors are accomplished folksong collectors and interpreters, and even a cursory search of the literature would have revealed the work of Pauline Greenhill on folk poetry. In ways the authors of Dead Horse don't, Greenhill (1989) in True Poetry efficiently explains the interrelationship between folksong, local song, and local poetry. Failure by Bartlett and Ruebsaat to establish a clear link between the genres, as well as their relevance in revealing the public culture of the community, is initially confusing and limits the readers' trust in the competency of the 